\title{
Distribution of the Many-lined Grass Slkink, Eutropis multifasciata (Kuhl 1820), in Bangladesh
}

\author{
Irin Sultana ${ }^{1}$, Naim Khandakar ${ }^{2}$, and Delip K. Das ${ }^{2}$ \\ ${ }^{1}$ National Centre for Biological Sciences, Bangalore, India \\ 2Department of Zoology, Jagannath University, Dhaka-1100, Bangladesh (naim.jnu.2014@gmail.com)
}

$\mathrm{T}$ he Many-lined Grass Skink, Eutropis multifasciata (Kuhl 1820), is an uncommon species known to occur in mixed evergreen forests and hilly areas in northeastern and southeastern Bangladesh (Hasan et al. 2014; Khan 2015; Khan 2018), with a recent report (Hossain and Jing 2019) confirming its presence in the northwestern part of the country. The species also is suspected of occurring in north-central Bangladesh (Hasan et al. 2014; Khan 2015). These skinks are associated with open forest floors, forest edges, and the vicinity of streams in primary and secondary forests and around human settlements (Hasan et al. 2014; Chakma 2015). However, the species had not been known to occur in southcentral coastal areas until now.

We observed two Many-lined Grass Skinks in Nijhum Dweep National Park, Bangladesh (22 ${ }^{\circ} 02^{\prime} 17.20^{\prime N} \mathrm{~N}$, $\left.91^{\circ} 00^{\prime} 37.50^{\prime \prime} \mathrm{E}\right)$ on 30 December 2019. This park, with a planted mangrove ecosystem, is a $163.52-\mathrm{km}^{2}$ offshore coastal island in the Bay of Bengal, located north of the lower Meghna Estuary and south of Hatiya Island (Iftekhar and Takama 2008; Hossain et al. 2016). Both individuals were basking in brushy vegetation (Fig. 1). They matched descrip- tions in Boulenger (1887) and Hasan et al. (2014). These observations extend the geographic distribution of E. multifasciata into the south-central coastal area of Bangladesh.

\section{Literature Cited}

Boulenger, G.A. 1887. Catalogue of the Lizards in the British Museum (Natural History). Second Edition. Volume III. Lacertidx, Gerrosauridx, Scincidx, Anelytropidx, Dibamidx, Chamæleonidx. Trustees of the British Museum, London, UK.

Chakma, S. 2015. Eutropis multifasciata, p. 122. In: IUCN Bangladesh, Red List of Bangladesh. Volume 4: Reptiles and Amphibians. IUCN (International Union for Conservation of Nature), Bangladesh Country Office, Dhaka, Bangladesh.

Hasan, M.K., M.M.H. Khan, and M.M. Feeroz. 2014. Amphibians and Reptiles of Bangladesh - A Field Guide. Arannayk Foundation, Dhaka, Bangladesh.

Hossain, K.T., M. Salauddin, and I.A. Tanim. 2016. Assessment of the dynamics of coastal island in Bangladesh using geospatial techniques: Domar Char. Journal of the Asiatic Society of Bangladesh, Science 42: 219-228.

Hossain, M. and C. Jing. 2019. Molecular phylogeny of Common Sun Skink, Eutropis fasciata (Squamata: Scincidae), of northwestern part of Bangladesh. Bangladesh Journal of Zoology 47: 13-25.

Iftekhar, S. and T. Takama. 2008. Perceptions of biodiversity, environmental services, and conservation of planted mangroves: A case study on Nijhum Dwip Island, Bangladesh. Wetlands Ecology and Management 16: 119-137.

Khan, M.A.R. 2015. Wildlife of Bangladesh: Checklist-cum-guide. M.J. Alam, Chayabithi, Dhaka, Bangladesh.

Khan, M.M.H. 2018. Photographic Guide to the Wildlife of Bangladesh. Arannayk Foundation, Dhaka, Bangladesh.
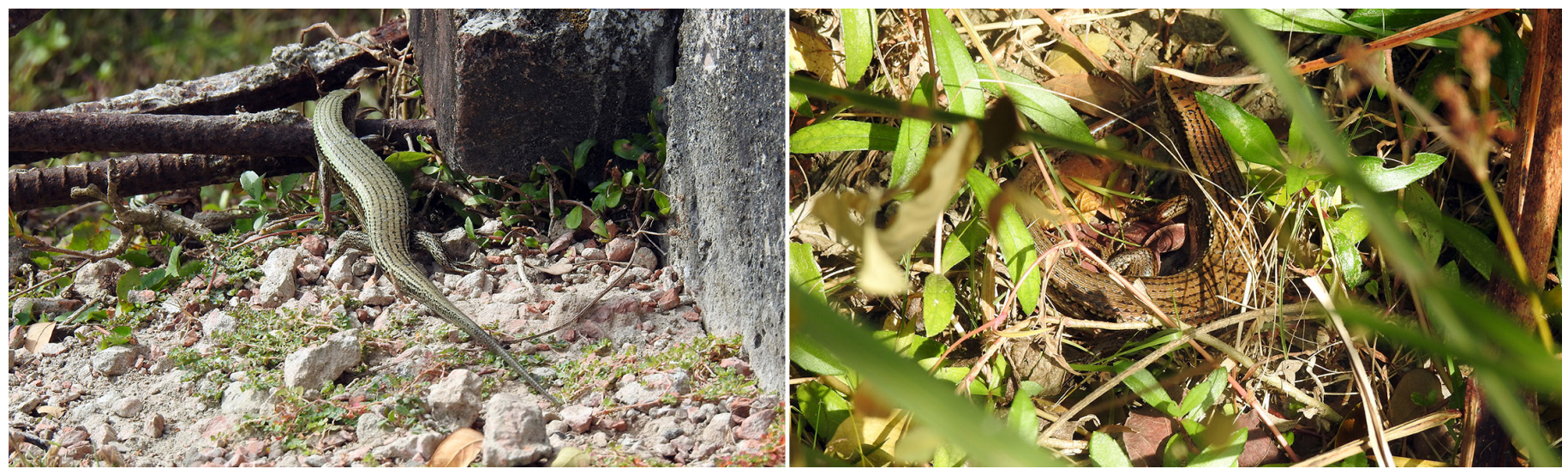

Fig. 1. Two Many-lined Grass Skinks (Eutropis multifasciata) in Nijhum Dweep National Park, Bangladesh. Photographs by Naim Khandakar. 